\title{
CONTROL AND ANALYTICAL ASSESSMENT OF INTERACTION BETWEEN CUSTOMERS AND PARTICIPANTS OF PUBLIC PROCUREMENT
}

\section{КОНТРОЛЬНО-АНАЛТТИЧНА ОЦНКА ВЗАЕМОДІЇ ЗАМОВНИКІВ ТА УЧАСНИКІВ ДЕРЖАВНИХ ЗАКУПІВЕЛЬ}

The preconditions of interaction between customers and participants of public procurement for new organizational forms of electronic trading have been defined in the paper, the notion of the customer has been analyzed and its characteristics have been identified according to the applicable law for the purposes of controllable transactions using public funds during procurement.

Keywords: customer of public procurement, accountability of public procurement, signs of customer of public procurement, interaction of participants in public procurement.

Formulation of the problem. The procedure and requirements for the participants in public procurement have been determined by Law, but the study of effective cooperation under the current system of public procurement contributes to finding new reserves for outcome and reducing corruption.

Today we can say that the current system of public procurement has entered into the stage that combines the traditional relationship between the customer and the supplier and the latest ones, based on the use of electronic platforms. Regarding the latter, its optional character in law field of Ukraine should be noted, in contrast to other countries. The introduction of the modern industrial society achievements where basic values (understanding the nature of the legal framework of public procurement, vendor identification, and identification of his activities as well, rationality, role of government, innovation, etc.) are being implicated as antipodes of values of preconditions for public procurement with the use of tenders. Besides, technological achievement have led the public procurement system to the stage of its radical changes in the context of its members role.

In the legal field and documentary software the old order has been changed by the dynamic "chaos" of auction, instability, gap of the traditional corruption ties, and it can and should be a new order of participants of procurement interaction. Identification of purchases customer allows to set the mandatory of tender procurement procedures while his spending public funds. So use of modern electronic form on trading platforms that provides effective interaction of procurement participants, eliminates corruptional component. We believe that this creates a new form of cooperation, so it needs adjustment of control and analytical procedures directed for identifying the effectiveness, feasibility, economical use of public funds for the purchase of services and goods in the public interest.

The researches of the following tasks of public procurement organization remain unexplored from the point of the system elements identification. In the case of use the synergistic approach, it should be admitted that this phase of the evolutionary process of interaction between supplier and customer was pawned by the whole course of previous periods of public procurement. Therefore the use of electronic platforms for interaction between participants of purchasing is an organic continuation of the public procurement system.

Analysis of recent sources and unsolved parts of the general problem. The new time has showed its latest contribution to understanding of the social values that are achieved through government procurement, initiated by the customer.

In very deed, its role is crucial in this process. In the beginning of establishment of normative regulation of participants in public procurement interaction the foundation for evolutionary approach to the economic role of procurement outcomes for society were made, so these results have been seen as a system of market-based principle. Relay was taken by the suppliers through the idea of selection during the tender in connection with the struggle for limited resources in a period of economic crisis. The evolutionary approach to the development of an economic phenomenon was studied by the theorists of economy T. Veblen, K. Menher, A. Marshall, J. Stiglitz. On the question of whether the economy is evolutionary science (Veblen) [1], and interdisciplinary research by A. Marshall who multiplied the meaning of evolutionary economics to the use of statements concerning evolutionary analysis of economic phenomena [2]. The most vivid illustration of the evolutionary approach gives a picture of long-term cycles by 
I. Wallerstein characterizing periodic fluctuations in essentially nonlinear system, called dissipative system, which shows continuous waves, in the terms of Synergy [3].

Therefore, we applied an evolutionary approach as the basis for identifying synergies interaction of customer and supplier in public procurement, according to the views of the economists of the previous years. Thus it is important to detect analytically if new values are prerequisites to the current system of legislative changes in the field of public procurement. In this approach, the most interesting ideas and principles to study such categories as "customer" and "state", "supplier" and "purpose of public procurement" will determine variability and the likelihood of achieving the objectives of public procurement. Foreign scientists have attempted to summarize the concept of the participants of public procurement [4, p. 23-41].

Experts estimate that the new collaboration platform between customers and participants of public procurement on an electronic basis will leave "in the past one of the most important ways for corrupt enrichment" [5].

The scheme of overvaluation when the auction was attended by the company related to the officials and politicians has been blocked. According to a senior economist of the International Centre for Policy Studies Basil Povoroznyk "it will a benefit not only for the state, that will significant money for purchasing goods and services. The companies, which previously had no a priori access to the public procurement market will participate in the trades"[5].

According to e-GP Prozorro, in 2014 the public procurements was made for 250 billion UAH. They passed through 25,000 tender committees that now exist in Ukraine. Meanwhile the loss of nontransparent government procurement for each day have been estimated by the activists of electronic trading introduction at 135 million UAH. [6].

Thus, the introduction of new forms of interaction between participants of public procurement requires a comprehensive assessment of its efficiency and effectiveness, since there is a need of legislative regulation. It is important to identify the existing contradictions between legal interpretations of the customer that initiates procurement in the expenditure of public funds.

The purpose of this article is to deepen the theoretical principles of interaction between customers and participants of public procurement through the concept of customer identification in terms of controllability and efficiency for the purposes of proper legislative regulation.

The main research. The most general concept of the customer as a legal entity that is an organizer, recipient of budgetary funds, is provided in the Budget Code.

According to paragraph. 38, p. 1, Art. 2 of the Budget Code of Ukraine recipient of budgetary funds is an entity, public or other organization that does not have the status of budget institutions and is authorized as a manager of budget funds to implement the measures imposed by budget program, and receives budget funds for their implementation [7].

So, if the legal entities (enterprises, institutions, organizations) and their associations that provide the needs of the state or local community, if such activities are carried out on an industrial or commercial base, are beneficiaries of the budget, such persons are the customers in understanding of Procurement Law regardless of the amount of such financing. They must comply with the Law on procurement in the procurement of goods, works and services, guided by the value limits defined by the Law on procurement during the budget period equal to one calendar year commencing 1 January of each year and ending 31 December of the same year, beginning with the date of budget funds receipt to implement the measures imposed by the budget program.

In turn, the Law of Ukraine "On public procurement" (further - the Law on Procurement) applies to all customers and purchase goods and services, provided that the value of procurement of goods (goods), service (s) is equal to or exceeds 200,000 UAH and work 1,5 million UAH. (ch. 1, Art. 2 PPL) [8].

The determined above value of goods, works and services procurement is reviewed every 12 months, taking into account the consumer price index, producer price indices of industrial products as well. As a result of viewing the Cabinet of Ministers of Ukraine submits, if necessary, to the Verkhovna Rada of Ukraine the draft Law on Amendments to the Law on Procurement.

Thus, it should be noted that the latest amendment to the to the Law on Procurement canceled the need to consider value added tax when determining the value of the purchase. At the same time, the Law applies to entities that according to Art. 1 carry out activities in certain designated areas of production, transportation, transmission, distribution, sale and supply of thermal energy, production, transportation and supply of drinking water, the provision of infrastructure rail transportation, the functioning of public electric transport and operation of its facilities for the provision of transport, services bus stations, ports, 
airports, postal services provision, geological study (including research and commercial development of deposits) of oil and gas mineral resources, deposits of coal and other solid fuels, the functioning and operation of fixed-line public communication or provision of public telecommunications services, transporting, storing, processing crude oil and oil products, the functioning electricity market, the market "day ahead" balancing market, ancillary services market, as well as providing services to the system operator, administrator calculations administrator commercial accounting, market operator, guaranteed buyer according to the Law of Ukraine "On principles of functioning of electricity market in Ukraine" ancillary services in the ancillary services and alignment of conditions for competition in accordance with the Law of Ukraine "On principles of functioning electricity market of Ukraine", gas production, transportation and supply $[9,10]$. Thus the state legislatively defined several categories of customers engaged in procurement for the special conditions. Determination customers in this law is clearly defined through the specification of what is not considered as an activity in areas relevant to the called ones.

The main focus of the Law of Ukraine "On peculiarities of procurement in certain sectors of economic activity" (hereinafter - the Law on features) has been made on the identification of the customer, because the rules only affect to customers, as defined therein, not general rules of PPL [11].

The Law about the features apply to customers purchasing goods and services to carry out their activities in the fields of Art. 2 of the features that:

fully or partially are made at the expense of budget funds, if the value of procurement of goods (goods), service (s) is equal to or exceeds 200 thousand UAH, and work -is equal to or greater than 1.5 million UAH, and is made at its own expense, if the cost of procurement of goods (goods), service (s) is equal to or greater than 1 million UAH, and work - 5 million UAH.

Thus, the procurement of goods, works and services fully or partially at the expense of budget funds should be guided by the customer Sec. 2 ch. 3. 2 of the features in the case of procurement of goods, works and services at their own expense to the customer should be guided by para. 3 h. 3.2 of the features.

So, for the purposes of controllability of performance of legal standards for public procurement it's advisable to clarify the concept of a customer in the context of the legislation for this sector.

Paragraph 9 Art. 1 PPL determined that customers are public authorities, local authorities and social security bodies established under the law, and legal persons (companies, institutions, organizations) and their associations that address the needs of the state or territorial communities if such activities are carried out on an industrial or commercial basis. The main factor is the presence of one of the signs: a legal entity manages, recipient of budget funds and (or) state authorities or local government or other customers if they hold a majority of votes in the supreme governing body of the legal entity in the authorized capital of the legal entity state or municipal part of shares exceeds 50 percent.

At the same time the category of customers are also customers defined in the Law on features. Thus, according to paragraph $1 \mathrm{ch}$. 1, Art. 1 of this legislative document, customers are determined as legal persons that carry out activities in any of the areas defined by Art. 2 of the features and meet at least one of the following characteristics:

public authorities, the authorities of the Autonomous Republic of Crimea, local governments own share in the authorized capital of the entity of more than 50 per cent or such bodies have the majority of votes in the supreme body of the entity or the right to appoint more than half of the executive body or the supervisory board of the entity and (or) the existence of special or exclusive rights. It is necessary to clarify the nature of special or exclusive rights. They are rights granted within the powers of a public authority or local government on the basis of any legal act and / or act of individual action that restricts activities in the areas defined by this Law, therefore one or more persons substantially affect the ability of others to carry out activities in these areas. The rights those were granted, including the results of tenders, during which the anticipated disclosure of their conduct, and if the grant of these rights was carried out on the basis of objective criteria, are not considered as special or exclusive.

Such characteristics for the definition of the customer are not enough, therefore, it is necessary to use the interpretation of a customer signs made by Ministry of Economics Development for the purposes of customer identification. According to its official position, legal persons (companies, institutions, organizations) and their associations independently determine the identity of customers in understanding the PPL and the Law Minister's explanation about the features on the definition of "customers" of 23.05.2014 r. [12].

However, the concept of industrial or commercial activity remains controversial because there is no its definition in the legislation. 
The most detailed definition of these concepts was prepared in the comments to the legislation of Ukraine on public procurement, prepared by the EU project "Harmonization of the procurement system in Ukraine with EU standards".

All public authorities, local governments as well as organizations and institutions funded from the budget having the status of a recipient of budgetary funds clearly acquire the status of the customer in understanding the law and must make purchases above threshold amounts solely for the procedures established by law.

Government needs are to be understood as state requirements necessary to performing by it its constitutional functions (lawmaking, public administration, economic regulation, tax collection, human rights, activity against crimes, maintaining integrity, inviolability of state borders, preservation of natural resources, etc.).

The need for a higher quality of life for the community, implemented in health care, education, security, transportation, municipal environment, cultural development and so on can be considered as one of the needs of local communities.

The fact of finding out the purpose provided by a particular interest of the state is the key to determine the status of the customer and distinction in cases where a legal person cannot be recognized by the client because he acts under normal competitive market, and therefore buys / manufactures and sells products (works, services) on a purely commercial basis for profit, not to ensure certain social needs, while keeping some advantages or even exclusive rights over other entities.

An important element to understand the concept of "customer" in the context of the law is the way in which the state or local governments provides its needs: 1) on a commercial or industrial basis; 2) the conditions set by decisions of public authorities that require entities to provide public or social needs in a certain way and on certain conditions.

The sign of procurement on an industrial basis can be interpreted as the acquisition of resources for its own production, allowing the company to increase the effectiveness of its own production or business management, to improve processes and to save resources ext.

The sign of activity on commercial base is treated as a supply of goods or services purely for profit in a market where a decision on the selection of products and their prices is taken by consumers on their own, and most importantly, all the economic risks of the results of such activity are taken by a legal entity (state and local government do not cover the expenses of the entity and do not regulate the prices of its products).

According to the given above explanations by Ministry of Economic Development activity is not a commercial or industrial if the state, controlled by it organizations are governed by other motives than profitability, while such activities are not dependent on the economic risk and the cost of it (as defined goal state organization exactly for such activities and regulations established method, conditions, prices, rates, etc.).

Instead, the activities are carried out on a commercial basis in cases if the needs of the state and local communities are provided with a competitive market.

The difference in maintenance requirements in the above mentioned cases is that in the first case, the state-controlled institutions (organizations) perform public functions and obligations to the state or community established by regulations, administrative decisions, statutes of legal persons, but are not voluntarily engaged in such activities on a commercial basis where profitability is the primary motivation.

Conclusions. Use of new forms for public procurement, e.g. electronic auctions, defined by foreign practices and experts as a means of overcoming corruption schemes, requires clarifying the concept of the customer in accordance with applicable law. It has been determined that the most common approaches to the definition of the customer according to the budget legislation are correlated with the norms of the law in the field of procurement and specify the characteristics of the customer based on the specifics of his activities. Therefore the national legislation created the preconditions for the introduction of electronic trading organizations that are initiated by customers with public funds. In such circumstances, public procurement must strengthen the accountability of transactions with public funds held by customers' purchases for the purpose of increasing transparency. It is also important to identify all state-level flows on the levels of goods customer, works and services for state funds to enforce social functions.

The prospects of further scientific developments in this direction are seen in future modelling of interaction between customers and executors of state contracts during procurement using such forms as noncompetitive procurement, the procurement procedure from one participant. Modelling an effective interac- 
tion in the public procurement system will allow to evaluate the application of the principles of procurement comprehensively for saving public funds at the appropriate level of quality goods and services that are the object of procurement.

\section{References}

1. Sotsialno-psykholohichnyi instytutsionalizm Torsteina Vablena. [Elektronnyy resurs]. Rezhym dostupu: http://pidruchniki.com/1957041140378/ politekonomiya/sotsialno-psihologichniy_institutsionalizm_ torsteyna veblena 1857-1929

2. Yukhymenko, P. I. (2005) Monetaryzm : teoriia i praktyka. Kyiv : Kondor, $312 \mathrm{s.}$

3. Sukhorukov, A. I., Kharazishvili, Yu. M. (2012) Modeliuvannia ta prohnozuvannia sotsialno-ekonomichnoho rozvytku rehioniv Ukrainy. Kyiv : NISD, $368 \mathrm{~s}$.

4. Demkina, A. V. (2012) Gosudarstvennye i munitsipalnye zakupki: problemy primeneniya grazhdanskopravovykh sanktsyi. Nauch. red. L. Yu. Mikheeva. Moscow : Norma : YNFA-M, 288 s.

5. Yak prozorishaiut derzhavni zakupivli. Internet vydannia VVS Ukraina. Rezhym dostupu : http://www.bbc.com/ ukrainian/business/2015/09/150916 state tenders_az

6. Systema elektronnykh derzhavnykh zakupivel [Elektronnyy resurs]. Rezhym dostupu : http://prozorro.org/

7. Biudzhetnyi kodeks Ukrainy vid 08.07.2010 № 2456-VI [Elektronnyy resurs]. Rezhym dostupu : http://zakon5. rada.gov.ua/laws/show/2456-17

8. Zakon Ukrainy «Pro zdiisnennia derzhavnykh zakupivel» vid 10.04.2014 № 1197-VII [Elektronnyy resurs]. Rezhym dostupu : http://zakon5.rada.gov.ua/ laws/show/1197-18

9. Zakon Ukrainy «Pro zasady funktsionuvannia rynku elektrychnoi enerhii Ukrainy» vid 24.10.2013 № 663-VII [Elektronnyy resurs]. Rezhym dostupu : http://zakon5. rada.gov.ua/laws/show/663-18

10. Zakon Ukrainy «Pro uhody pro rozpodil produktsii» vid 14.09.1999 № 1039-XIV [Elektronnyy resurs]. Rezhym dostupu : http://zakon5.rada. gov.ua/laws/show/1039-14

11. Zakon Ukrainy «Pro osoblyvosti zdiisnennia zakupivel $\mathrm{v}$ okremykh sferakh hospodarskoi diialnosti» vid 24.05.2012 № 4851-VI [Elektronnyy resurs]. Rezhym dostupu : http://zakon3.rada.gov.ua/laws/show/4851-17

12. Lyst-roziasnennia Ministerstva ekonomichnoho rozvytku i torhivli Ukrainy vid 23.05.2014 № 3302-05/16628-03 [Elektronnyy resurs]. Rezhym dostupu : http://www.ua-tenders.com/legislation/explanations/246211/

\section{Список використаної літератури}

1. Соціально-психологічний інституціоналізм Торстейна Ваблена [Електронний ресурс]. - Режим доступу: http://pidruchniki.com/1957041140378/politekonomiya/sotsialno-psihologichniy_institutsionalizm_torsteyna veblena_1857-1929

2. Юхименко П. І. Монетаризм : теорія і практика : [монографія] / П. І. Юхименко. - К. : Кондор, 2005. $312 \mathrm{c}$.

3. Сухоруков А. І. Моделювання та прогнозування соціально-економічного розвитку регіонів України : [монографія] / А. І. Сухоруков, Ю. М. Харазішвілі. - К. : НІСД, 2012. - 368 с.

4. Демкина А. В. Государственные и муниципальные закупки: проблемы применения гражданско-правовых санкций : монография / [науч. ред. Л. Ю. Михеева]. - М. : Норма : ИНФНА-М, 2012. - 288 с.

5. Як прозорішають державні закупівлі [Електронний ресурс] / Інтернет видання ВВС Україна. - Режим доступу : http://www.bbc.com/ukrainian/business/2015/09/150916_state_tenders_az

6. Система електронних державних закупівель [Електронний ресурс]. - Режим доступу : http://prozorro.org/

7. Бюджетний кодекс України від 08.07.2010 № 2456-VI [Електронний ресурс]. - Режим доступу: http://zakon5.rada.gov.ua/laws/show/2456-17

8. Закон України «Про здійснення державних закупівель» від 10.04.2014 № 1197-VII [Електронний ресурс]. Режим доступу : http://zakon5.rada.gov.ua/laws/show/1197-18

9. Закон України «Про засади функціонування ринку електричної енергії України» від 24.10.2013 № 663-VII [Електронний ресурс]. - Режим доступу : http://zakon5.rada.gov.ua/laws/show/663-18

10. Закон України «Про угоди про розподіл продукції» від 14.09.1999 № 1039-XIV [Електронний ресурс]. Режим доступу : http://zakon5.rada.gov.ua/laws/show/1039-14

11. Закон України «Про особливості здійснення закупівель в окремих сферах господарської діяльності» від 24.05.2012 № 4851-VI [Електронний ресурс]. - Режим доступу : http://zakon3.rada.gov.ua/laws/show/4851-17

12. Лист-роз'яснення Міністерства економічного розвитку і торгівлі України від 23.05.2014 N 3302-05/1662803 [Електронний ресурс]. - Режим доступу : http://www.ua-tenders.com/legislation/explanations/246211/ 


\section{М. С. Письменна \\ КОНТРОЛЬНО-АНАЛІТИЧНА ОЦІНКА ВЗАЕМОДІї ЗАМОВНИКІВ ТА УЧАСНИКІВ ДЕРЖАВНИХ ЗАКУПІВЕЛЬ}

Вступ. Державні закупівлі, що здійснюються замовниками державних робіт, послуг, виконують суспільну функцію задоволення постійних потреб населення країни при визначених пріоритетах розвитку. Витрачання державних коштів на суспільні потреби, за оцінками фахівців, зарубіжних експертів, є однією з найбільш корумпованих сфер державного сектору економіки. Тому питання контролю операцій закупівель за державні кошти є актуальним завданням досліджень як у теоретичній, так і практичній площчині.

Метою дослідження є поглиблення теоретичних засад організачії взаємодії замовників та учасників державних закупівель через ідентифікацію поняття замовника з точки зору контрольованості та ефективності для иілей належного нормативного регламентування.

Проблема. Існуюче протиріччя між традииійними та новітніми формами взаємовідносин між замовником та постачальником в сучасній системі державних закупівель не дає змогу виконувати суспільну функиію соціального забезпечення населення у найбільш економний та ефективний спосіб. Причини в тому, що традиційні форми взаємовідносин між учасниками державних закупівель місять корупиійну складову, а новітні форми (такі як електронні закупівлі через відповідні платформи взаємодіi) не є обов'язковими та регламентованими законодавчо. Отже, невирішеними питаннями є ідентифікаиія замовника в регламентованому нормативному полі та оцінювання можливості взаємодіі відповідно до новітніх форм держсавних закупівель.

Виклад основного матеріалу статті. Аналіз поняття замовника, як найбільш загального поняття в межах чинного законодавства показав, що ие є розпорядник, одержувач бюджетних коштів (згідно з нормами Бюджетного кодексу). А оскільки на сьогодні в Україні діють два профільні закони про закупівлю, автором зроблене критичне оцінювання підходів до визначення замовни$\kappa а$ відповідно до изих документів $i$ наведено критерії та ознаки, за якими визначають обов'язковість проведення процедур закупівель при використанні державних коштів. Це дозволило посилити контрольованість обсягів витрачання державних коштів з огляду на правильну ідентифікаиію замовника.

Результати та їх обговорення. Взаємодія учасників державних закупівель на стадї̈ визнання замовника та необхідності проведення тендерних процедур посилює відповідальність усіх учасників за ефективне використання коштів держави під час закупівель товарів, робіт та послуг для виконання сочіальних функиій для громадян.

Висновки та рекомендації. Встановлено, що найбільш загальні підходи до визначення поняття замовника згідно з бюджетним законодавством корелюються із нормами чинних законів про закупівлю та уточнюють ознаки замовника, виходячи зі специфіки його діяльності. Ідентифікація поняття замовника в системі державних закупівель дозволила зробити висновок, щя у вітчизняному законодавстві створено передумови для впровадження організаиії електронних торгів як обов'язкової форми взаємодії, що дозволить усунути корупиійну складову традиційних форм взаємовідносин учасників тендерних торгів.

Рекомендовано з метою посилення прозорості державних закупівель посилити контрольованість здійснюваних операцій за державні кошти, проведених замовниками закупівель. Для підвищення ефективності використання державних коштів під час державних закупівель важливо ідентифікувати усі державні потоки на рівні замовників товарів, робіт та послуг за кошти держави для забезпечення виконання сочіальних функиій.

Ключові слова: замовник державних закупівель, контрольованість державних закупівель, ознаки замовника закупівель за державні кошти, взаємодія учасників державних закупівель. 